\title{
The Arctic Tern in Saskatchewan
}

by Robert W. Nero, Saskatchewan Museum of Natural History

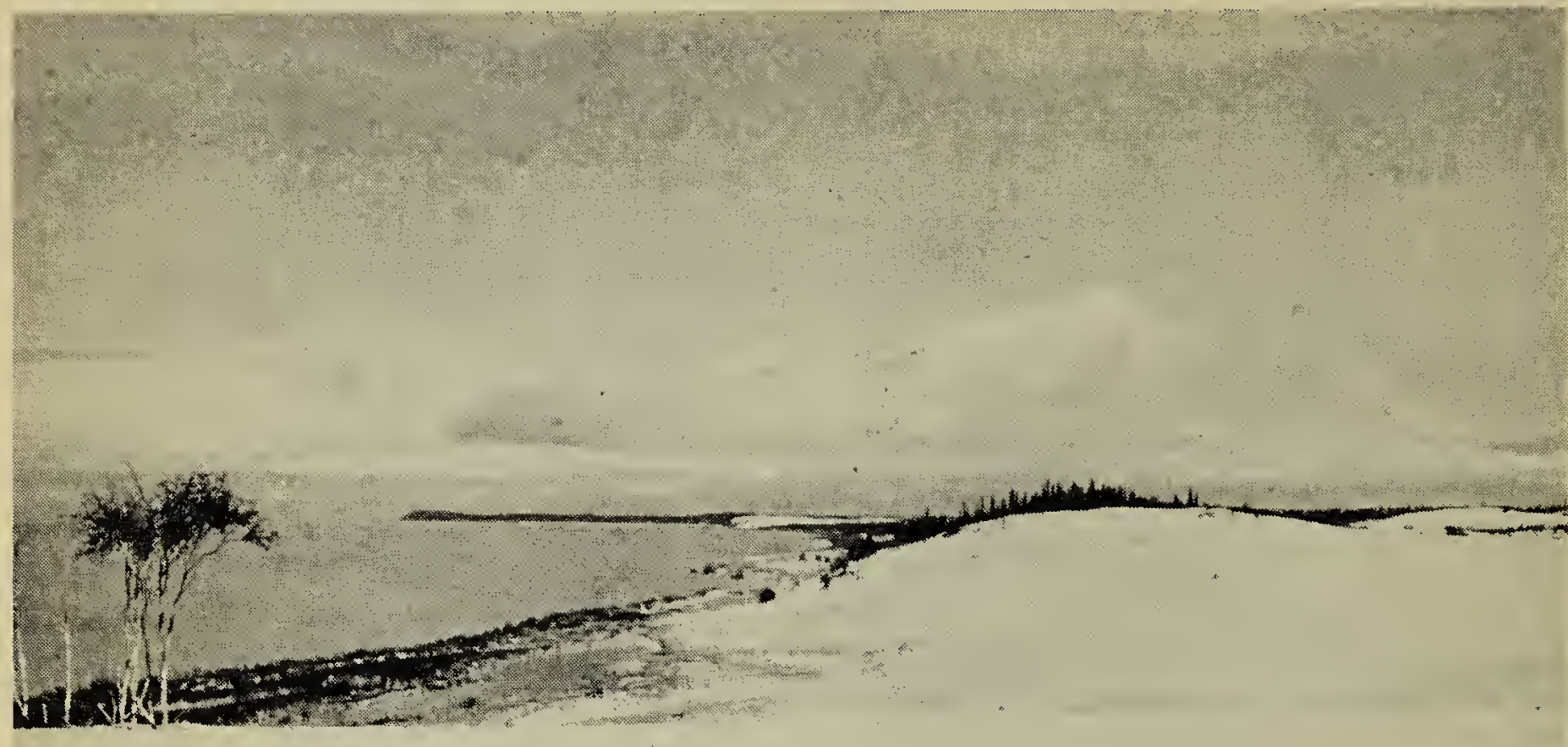

Photos by F. W. Lahrman, S.M.N.H.

View of south shore of Lake Athabasca, looking east to Beaver Point

During May, June and July, 1960, a party from the Saskaitchewan Museum of Natural History, Department of Naitural Resources, consisting of Ralph D. Carson, Fred W. Lahrman and myself, conducted a survey of the birds of the Uranium City area and adjacent Lake Athabasca*. The full results of this work are in preparation; the objective of the present report is to describe our observations of the nesting of the Arctic Tern (Sterna paradisaea) on the south shore of Lake Athabasca, 35 miles southwest of Uranium City.

We were on the lake on 15 different days, from June 10 to July 26, and during this period we also spent seven days on the south shore of the lake, between Beaver Point and the William River. We travelled in an 18-foot outboard motorboat owned and operated by Albert Scarfe (Dept. of Mineral Resources, Uranium City) and also had the use of a similar boat belonging to the Dept. of

* Currently accepted spelling.
Natural Resources. We are especially indiebited to Al Scarfe as well as to Grant Fladager, Conservation Officer, for assistance in this respect. James Baillie, Jr., Royal Ontario Museum of Zoology, kindly made available T. M. Shortt's unpublished Lake Athabasca bird records. Dr. John W. Aldrich, U.S. Fish and Wildlife Service, sent me a copy of a list of birds collected by a Biological Survey party on Lake Athabasca in 1920. Dr. Raymond A. Paynter, Jr., Museum of Comparative Zoology, and Dr. Herbent Friedmann, U.S. National Museum, provided information on certain specimens in their respective collections. Dr. Francis Harper, Chapel Hill, North Carolina, read the manuscript and freely offered advice and encouragement.

\section{Previous Records and Status}

The first record of an Arctic Tern in Saskatchewan was obtained by Francis Harper, who found this species to be common from June $\mathbf{2 6}$ to 30,1914 , at the mouth of the Char- 
lot River (northwest of Black Bay, north shore of Lake Athabasca) "where they were presumably breeding" (Harper; 1915). 'The first specimen was collected on June 27, 1914 (pers. corres., 1916). Harper was the zoologist of a party from the Geological Survey of Canada which made a traverse from Lake Athabasca to Great Slave Lake by way of the Tazin and Talitson Rivers in the summer of 1914 (see: Harper, 1931, for a discussion on the ecology of the area). Six years later, Harper, while chief of a U.S. Biological Survey party which included Hamilton $\mathbf{M}$. Laing and J. Alden Loring, definitely established the breeding status of this species when he collected an adult male Arctic Tern (U.S.N.M. \#283461) and a chick (M.C.Z. \#231651) on August 7, 1920, at a point about three miles south of Poplar Point (on the east end of Lake A.thabasca). On August 9, an immature (M.C.Z. \#231650) was collected on an islet about three miles east of the MacFarlane River. Additional sight records of suspected Arctic Terns were made at Poplar Point, August 12; south of the islands off Crackingstone Point, July 25; and at Maurice Point, August 20.

In 1921, E. W. Nelson, Chief of the U.S. Biological Survey, senit to the Saskatchewan Museum of Natural History (then the "Provincial Museum") a list of the specimens collecter on Lake Athabasca (in Sask.) by the 1920 survey. This list and comments by Nelson were published by Bradshaw (1921). The Arctic Tern chick, which had evidently not been certainly identified at the time, is not specifically mentioned, the report stating-only that the Arctic Tern was found "apparently on its breeding ground..." A similar statement was later published by Mitchell (1924). No further information on the Arctic Tern in Saskatchewan seems to have been published.

The above records are apparently the basis for the inclusion, by the A.O.U. Check-list Committee, of northeastern Alberta and northwestern Saskatchewan (Lake Athabasca) within the breeding range of this species (A.O.U. Comm., 1957). T. M. Shortt, who worked on Lake A thabasca from June 10 to July 22, 1945 , did not record the Arctic Tern (unpublished records, R.O.M.Z.). Salt and Wilk (1958), in their recent Birds of Alberta, say only that there are several records of Arctic Terns from Lake Athabasca. Snyder (1957) does not include Lake Athabasca within even the summer range and the nearest breeding locality reported by him is in the Northwest Territories about 300 miles northeast of Uranium City. However, in 1901, Preble (1908) found Arctic Terns breeding on the lower Slave River (and on Great Slave Lake) about 200 miles northwest of Uranium City.

\section{OBSERVATIONS}

With the meagre published information referred to above in mind we naturally were looking for Arctic Terns and hoped to find nest sites. On June 15, on our third trip on the lake, we collected two Arctic Terns at a Common Tern (Sterna hirundo) colony near Prospectors Bay on the north shore of Black Bay. One of these was evidently a member of a pair; the other had been perched on a rock on the islet on which the Common Terns were nesting. We necognized Arctic Terns in the air only with considerable effort. The quick erratic movements of the bird, plus the movements of our boat,' made it ditficult to get a good look at them, and when we were on solid rock it was still difficult. We found the blood-red beak to be the best distiguishing character; and in general, the orange color of the beak of the Common Tern, plus the black area near the tip (on both mandibles), was strikingly different when seen in good light at closé range. The appearance of some Arctic Terns with blackish color on at least the upper

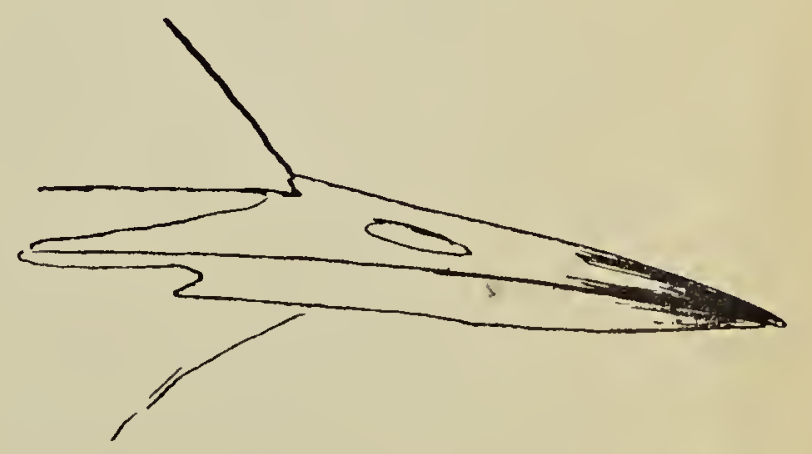

Field sketch by Fred W. Lahrman

Beak of male Arctic Tern collected June 15, 1960 showing extent of black pigmentation. 
mandible was confusing. The male collected on June 15 had a very noticeable black area on the beak (see sketch); a breeding female collected on July 8 and a male on July 10 , also had this character. The black mark was not. as extenisive as in Common Terns, and did noit prevent our noticing the really blood-red color of the rest of the beak. Ridgway (1919:499) states, probably on the basis of dried and discolored museum specimens, that the bill tip is usually blackish. Peterson (1947) says the bill is blood-red to the tip, but adds that in fall adults the bill (and feet) become quite dusky (solid black according to Pough, 1953). Peterson et al (1954) state: "wholly bloodred bill (wholly blackish in winter, and tip may still be black in spring)." Comparisons with the Common Tern on this basis are complicated in that some Common Terns "lose the black bill-tip for a while in late summer" and some individuals of boith Common and Forster's Tern (Sterna forsteri) may lack the usual black tip (Peterson, 1947). Earl Godfrey considers the higher pitched voice of the Arctic Tern the best means of distinguishing it from the Common Tern (Godfrey, 1954). This call, plus the beak color and the noticeably shorter legs when perched, should identify it, but where possible, specimens ought to be collected to establish its identity outside of its known range.

On June 18 we returned to the same Common Tern colony and, suspecting that Arctic Terns were also nesting here, set up a blind and patiently checked the occupants of each nest. Although all of the residents proved to be Common Terns, one Arctic Tern was seen contesting with a resident Common Tern. We came back again on June 30 and once more checked nest occupants in this colony as well as in a smaller colony on an adjacent islet, but again found only Common Terns. However, on this date we collected another Arctic Tern from the resident flock which hovered over our heads. A final check made on July 5 was also negative, although one individual briefly seen resting in the colony appeared to be an Arctic Tern. However, our time was limited and as we felt it was useless to check further in this area, the search was abandoned.

We then proceeded, as earlier planned, to visit the south shore of Lake Athabasca, in particular the immense sand dune area found in this region. We left Bushell (which is the port for Uranium City, at the head of Black Bay) on July 7, accompanied by $\mathrm{Al}$ Scarfe and his young nephew, Jim Prpick. Owing to sudden rough water we were forced to camp overnight on Johnston Island. Early the next morning we made a good crossing on calm water, landing easily on a wide sand beach at Beaver Point. (We were told that ordinarily it is difficult to land in this region because of the wide expanse of shallow water over offshore sand flats. However, the lake level in 1960 was very high). A few unidientified terns and a jaeger were seen en route. Later in the day after investigating the exitensive spruce and jack pine forest on top of the high ridge at Beaver Point, we moved to set up camp at the base of a dune, abnut five miles west of Beaver Point. (Poplar Point, the site of the 1920 record, is about 42 miles northeast of Beaver Point.) The open dunes in this region occupy about 36 square miles, ranging inland four to six miles, and up to 10 miles in length, between Beaver Point and the William River (west of the William River, there are dunes occupying an area of about 100 square miles). These dunes are, to a large extent, so extensive and devoid of vegetation that they often cast a pinkish reflection on the clouds overhead, which may be seen many miles away. However, there are extensive patches of spruce and especially jack pine at places. along the beach terrace, and adjacent to springs, creeks and interior lakes. The very fine sand which comprises these large dunes is supposed to come from the weathering of underlying sandstone bedrock (Athabasca formation) which forms the entire southern edge of the lake and which extends nearly to Wollaston Lake on the east and south to Cree Lake (Gussow, 1959).

Our camp was located on a stabilized dune next to the beach and beside a stand of white spruce. In the massive sand dunes which surrounded our island of forest one could see both living trees being buried and the weathered stumps of long-buried trees being uncovered. The dune landscape on the whole 
was austere, yeit dramatic and exciting; the dark, almost black, spruce clumps provided a welcome contrast with the vast open areas of cleanswept sand. We found cast up on shore one or two objects atitributable to recent man, buit otherwise the region was pleasantly unspoiled and wild. Tracks in the sand daily told the story of secretive and nocturnal animal activities; wolf tracks near our tent were examined with considerable elation, and moose and bear sign was common. The bird life was varied but not plentiful, about 30 species being recorded on our first three days in the area. While on the south shore we were frequently plagued by wind and blowing sand, rain and innumerable blackflies and mosquitoes, but we thoroughly enjoyed our visit. Francis. Harper recently recollected his own experiences in the area: "All of this brings back some fond memories of our little party's experience on Athabaska more than 40 years ago. Like you, we had been attracted over to the south shore by the sandy-hued reflections in the sky above the marvellous sand-dune country. Our days at Poplar Point and MacFarlane River were few but glorious." (Pers. corres., 1961).

Archaeological remains are often found uncovered in sand dunes and it was mainly in a search for such sites that we hastily set out from camp late in the afternoon on July 8. Carson and I climbed an immense dune close to camp and almost at once were astonished to see a term attacking a Sparrow Hawk (Falco sparverius) which was evidently nesting in a dead white spruce which projected above the edge of the dune. After the bird was identified as an Arctic Tern, it was collected, and when a second tern suddenly appeared and hovered over the fallen bird, it too was collected. Upon examination we found that we had collected a male and a female Arctic Tern, both of which appeared to be in full breeding condition. Startled and perplexed at this unexpected occurrence of Arctic Terns, we continued walking along the top of the dune. A few minutes later, while examining firestones and flint chips in a prehistoric camp-site, which we founa about 150 yards away, we made the then astonishing discovery of two brown eggs, unmistakably tern eggs, lying in a shallow depression on the bare sand. It was at once clear that this was an Arctic Tern nest and that we had collected the resident pair. This nest site was about 350 yards inland from the beach and about 75 to 100 feet above the lake level.

The rate at which the sand shifts in these dunes when the wind is blowing wias amply demonstrated ait this time, for when we returned with Lahrman to photograph the site, about 20 minutes later, the eggs were already partly buried. Bath eggs were pipped, so they were carried back to camp and carefully incubated "by hand" by Carson during the night. One chick which survived and hatched the next day was prepared a day later as a specimen.

Several ather ternis were seen in the vicinity after we photographed the nest. One briefly attacked a Raven (Corvus corax) which was walking on the ground. This led us to suspect the presence of other nests but we were unable to find any. Many of the terns which were seen at this time (and later) were carrying minnows, presumably to be fed to young birds or to incubating

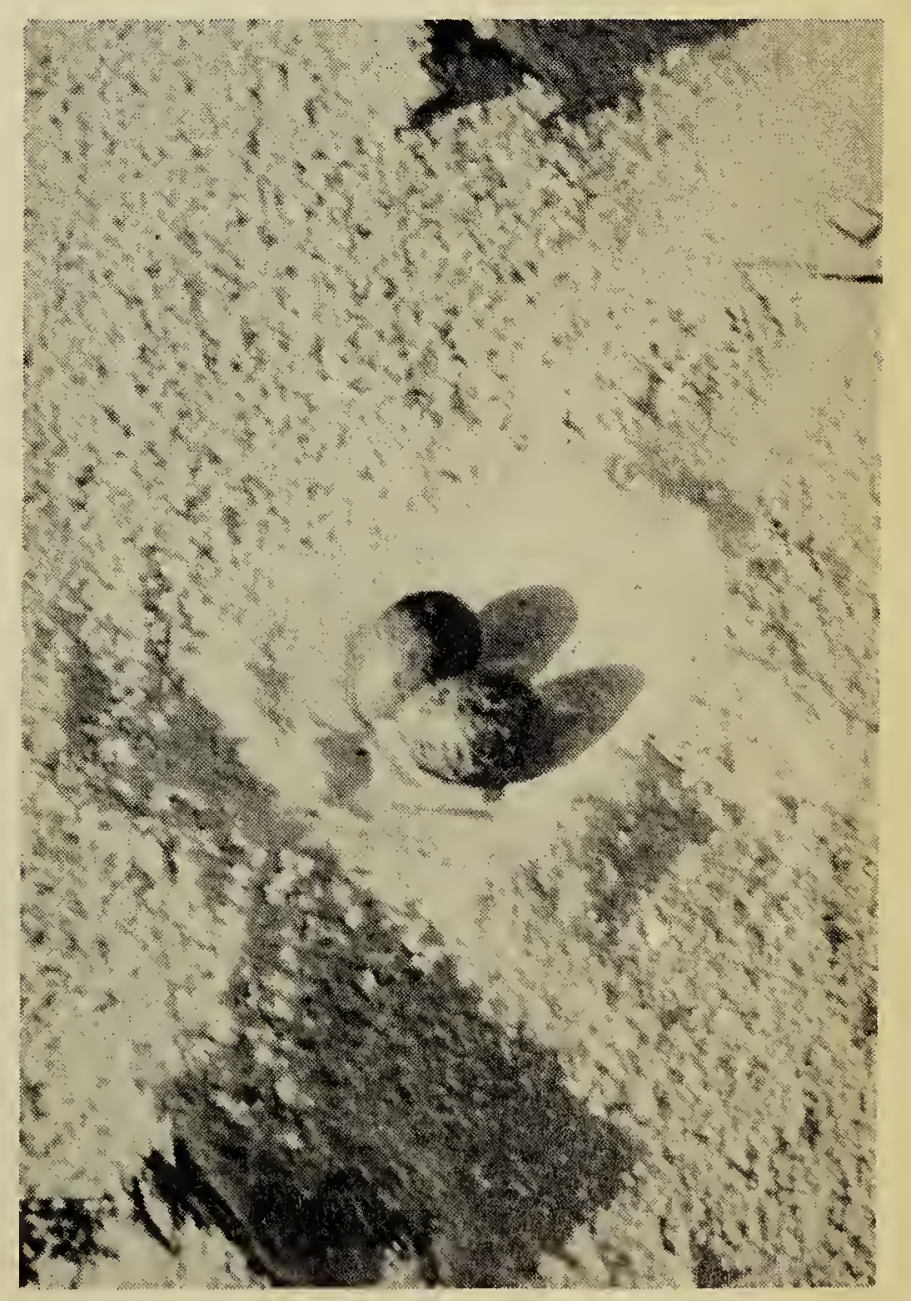

Eggs of Arctic Tern. Note contrast between the dry nest protected by the in. cubating bird and the rain-marked wet sand around it. 
mates. (A tern collected at a later diate was carrying a five-inch minnow, apparently an Emerald Shiner (Lake Shiner) (Notropis atherinoides). Small fish captured in the offshore shallow water of the lake appeared to be a major source of food; terns were daily seen fishing offshore, even in the roughest weather.) Careful atitempts to follow terns led us over the dunes about two miles inland, and from this point we could still see terns flying even further inland. All of these terns flew in very erratic and swift flight and were difficult to follow.

On the next day (July 9) while hiking in the dunes trying to locate ather nosts. we saw a tern suddenly fly up Irus. - distant ridge. Fortunately, two of uis who were far apart at this moment both happened to see the bird leave the ground. We proceeded directly to the spoit and by carefully searching where our paths crossed soon found the nest which contained one egg. At our approach to the nest, and while we were still some distance, the first tern had flown up high above the nest site and was immediately joined by another. The first bird hovered over the site briefly then approached us and hovered overhead, giving an alarm cry like that of the Common Tern. Then the pair shortly flew away and were not seen again while we were in the vicinity of the nest. We returned later in the day, built a blind of stumps about 50 feet from the nest and left Lahrman in it, halfburied in the sand, but after two hours the birds had still not returned.
On the following cloudy and misty day, however, both birds reiturned to the nest, permitting a series of photos and observations. from the blind. Lahrman's field notes follow:

\section{JULY 10:}

10:30 a.m.-A tern arrives and settles on nest three minutes after Al Scarfe's departure. Bird very alert on nest, helad constantly turning in a watchful attitude. Once it. gave a low "teite-tete" call. Assumed to be the female.

$\mathbf{1 0 : 4 5}$ a.m.-It called again in a similar manner and I could hear a distant bird answering "tek-tek". Then she walked off nest, calling steadily "tete-tete-tete" with open beak. Suddenly the male appeared before her calling "tek-tek-terr" then evidently fed her. The male then quickly flew up out of my sight, the female called as before, walked a few steps further, then turned and started walking toward the nest. But the male suddenly dropped onto the nest and the female then flew away. Presumed male bird sat on nest with head very high and appeared very unsettled. A minute later he silently flew off and the female immediately returned to the nesit and seittled down.

12:12 p.m.-Female on nesit called "tek-tear, tew-tew-tew" to a passing tern which called "tek-tearr" several times.

12:16 p.m.-Female suddenly called "tek-tek', te-te-te-te" and constantly "te-te". Male called "tear, tear". Female faced downwind (op-

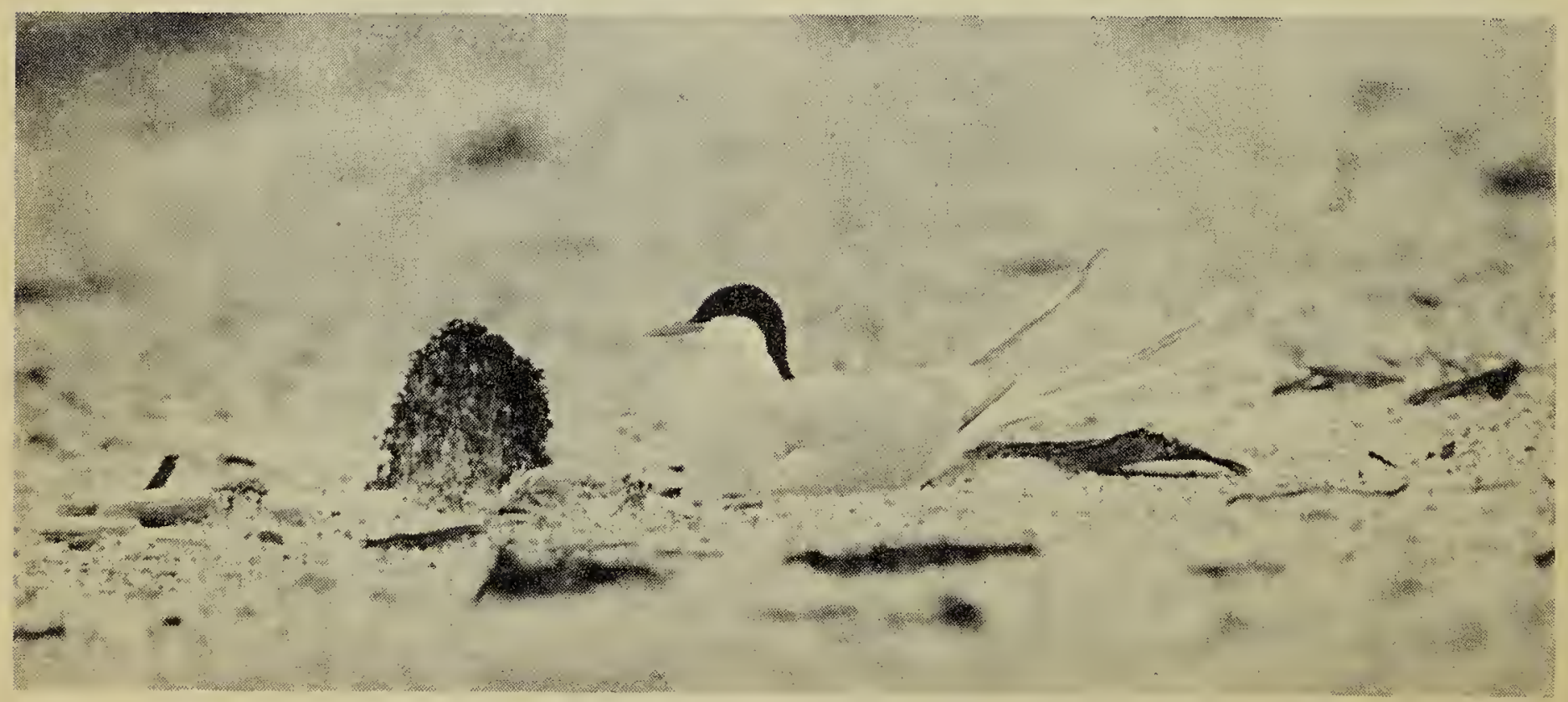

Arctic Tern incubating, Lake Athabasca, July 10, 1960 
posite to normal position), male swooped down and fed her a minnow in one swoop with scarcely a pause in flight, and departed silently. Female shuffled about to face wind again.

12:25 p.m.-Female suddenly called "tek-kew, tek-kew" and held head and neck outstretched and flat on the ground with open beak as a passing tern called "tiearr."

12:42 p.m.-Female behaved in similar manner as above but I heard no call from another tern as before.

1:10 p.m.-Female called as before (when being fed) and walked a few inches away from the nest. The male alighted-fed the female a minnow, then flew up and alighted again about six feet from the nest. The female flew up but I could see her shadow flitting over the sand as she hovered about; meanwhile, the male stood by for about one minute; then he started walking toward the nest, flew to the neist and settled down as before with his head held high. He remained in this posture for about a minute, then called "tick-tick" a few times and flew off. The female at once reiturned and sat on the nest. I left the blind at 1:30 p.m.

On this same day (July 10) a further attempt was made to find nests in other areas. Terns were seen everywhere we searched, but their habit of leaving the nesit at a distance of a quartier of a mile or so ait our approach, suddenly springing up from a ridge, first flying towards us and then away from us, made nestfinding difficult. However, in the evening Lahrman discovered two nests less than one-quarter of a mile east of the location of the first nesit we had found. At his approach to this new area several terns flew toward him, hovered overhead with alarm cries, and then by their presence and behavior revealed their nesits. I joined Lahrman at this time and took noites while he photographed the birds and their nesits. A pair which had one egg and one newlyhatched young were especially vigorous in demonstraition, actually striking our heads repeatedly (as reported by others, e.g., A. Twomey in Taverner and Sutton, 1934). Another bird remained on the second nest

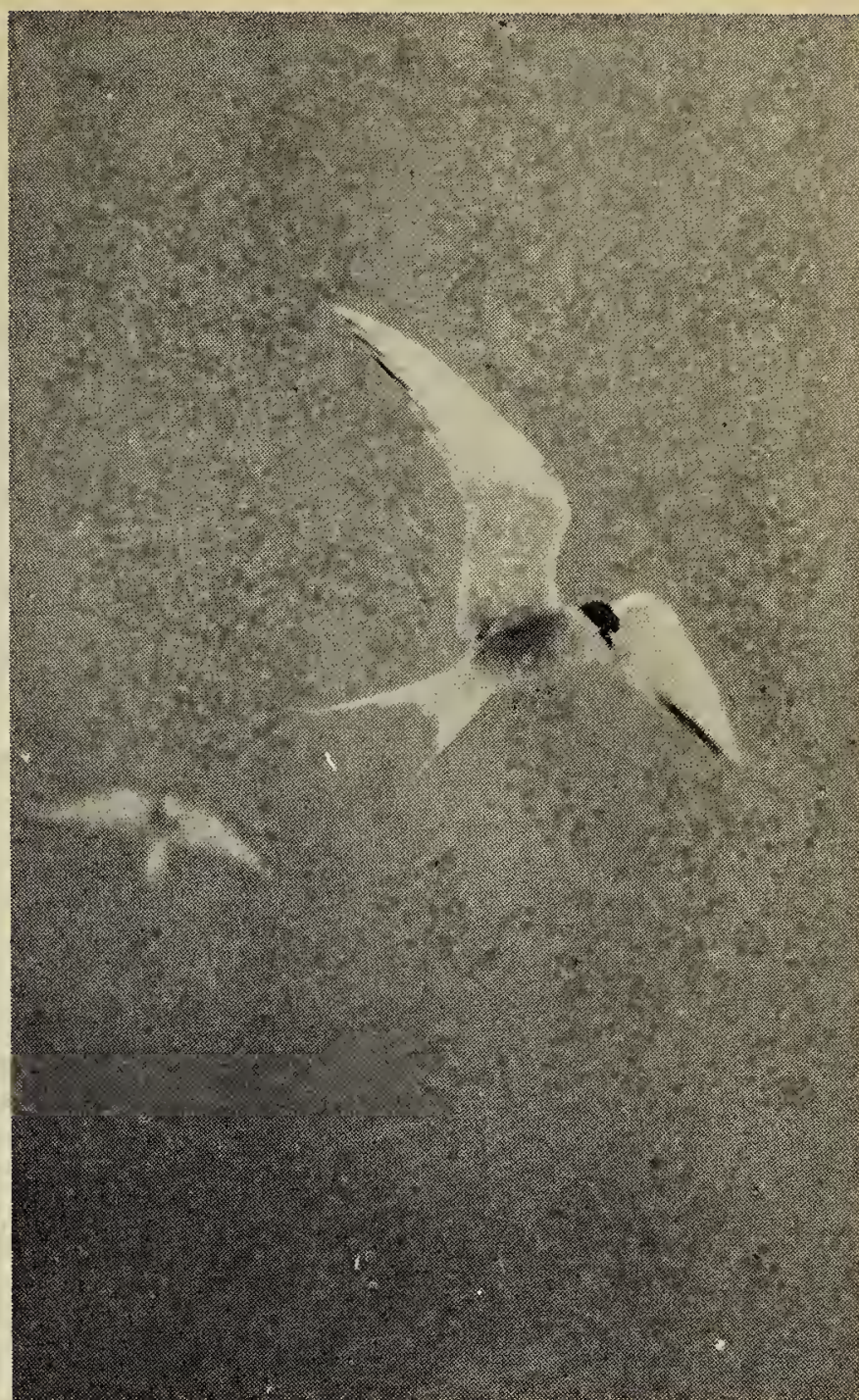

At some nests, Arctic Terns showed considerable aggressive behaviour, swooping at intruders.

(which contained two eggs and which was about 90 yards awlay from the first) until very closely approached by us. Both pairs of birds remained at their nest sites during the course of half an hour or more. Of course, we were very surprised by this behaviour which contrasted so strongly with that of the other terns which we had previously encountered.

We left the south shore on July 11 for our home base, and returned again on July 22 after having been forced to "wait out" bad weather for three days on Long Island. On this second trip we were transported across the lake by Grant Fladager and one of his assistants, Raymond Heron. Carson, Lahrman and myself were left on the south shore from then until we were picked up early in the morning of July 26 by Al Scarfe. During the four days of our stay we attempited to explore the dune area funther and made two lengthy trips. On July 22 we walked inland about six miles to the limit of 
the dunes. About four miles south of the coast we encountered two large flocks of terns, about 100 in all, that appeared to have young in the area. These two groups had been resting on the tops of large pebbly ridges where we found numerous tracks, droppings, and some possible nesitscrapes. Although we searched the area for a considerable time we were unable to find any active nests or young. Red Fox (Vulpes fulva) tracks were very numerous and we saw many indications that they were preying on the terns. In one place we found Arctic Tern shell fragments and signs which suggested that a fox had robbed a nesit and had been mobbed by terns. Fox scats which we found in the vicinity contained numerous tern feathers. Late in the afternoon on our way back through this region, we actually startled a Red Fox from these open sands. Inland, where the sands of this small desert man into a series of lovely lakes, Arctic Terns wiere even seen perched on top of black spruce trees, an extraordinary sighit.

On July 24 we checked the nests which we had found previously. The nest where we had set up a blind had one egg which was still being incubated. At the other two nests, three young were found which were half-grown and could run rapidly. When we caught up to one scurrying young it suddenly stopped, crouched down and remained motionless. We watched the young from one nest run off at our approach, then stop and hide beneath or beside a log or sitone. When the parent bird settled on the ground some distance away, the young gradually walked back until they were at her side. If this is usual behaviour it would help account for our inability to find the young at other nest sites. (Parmelee and MacDonald, 1960, report a chick 12 days old about 150 yards from its nest).

On the following day (July 25) we made a six mile walk across the dunes to the William River, and again saw terns everywhere throughout the area. A single nest with two eggs, one just pipping, was found on an extensive pebble plain in this region, and dozens of nearby terns which drifted overhead and which also perched on the ground suggested the probability of many other nests.
Terns were also seen fishing in the sandy waters of the William River and returning to the dunes on this side. Strangely, we never saw young on the wing, and presume that the young continue to walk about on the sand for long distances after they have reached a considerable size. There was much evidence for this in the numerous tern tracks which we found traversing nearly every dune. Although in the end we found only five active nests, we had ample reason to believe that there were actually hundreds of terns nesting in the dune area.

Their habit of solitiary nesting and their wary behaviour presumably represents an adaptive response to breeding on a mainland where they are apparently subject to predation by skunk, wolf, and, probably most important, fox. Colonial habits under these circumstances would appear to be disastrous, although the mobbing behaviour at a large colony would undoubtedly pose a threat to some extent. Parmelee and MacDonald (1960) sitate that the Arctic Tern is well known for its ability to defend its eggs and chicks against enemies, but they also report that on Ellesmere Island dogs, which occasionally ventured into tern territory, were atitacked though "not effectively." Hawksley reports (1957:70) "The Arctic Tern's habit of frequently nesting singly on the mainland in Arctic regions may be effective in reducing predation, especially from mammalian predators such as the Arctic Fox."

Arctic Terns are reported to nest in varying numbers and in varied fashion. Grinnell (in Bent, 1921) in Alaska did not find them in colonies, nests seldom being within 100 yards of each other. Some were found nesting on the tundra a quarter of a mile from the nearest lake. On the other hand $\mathrm{A}$. Twomey found ten thousand nesting on islands near Churchill, Manitoba, nests being only a few feet apart (Taverner and Sutton, 1934). It is of some interesit to note, too, that although this circumpolar species breeds primarily in the Arctic they normally range southward along the Atlanitic coast, breeding commonly off Massachusetts, some 500 miles farther south than anywhere else in the world (Pough, 1953). According to Pough "the 22,000 mile 


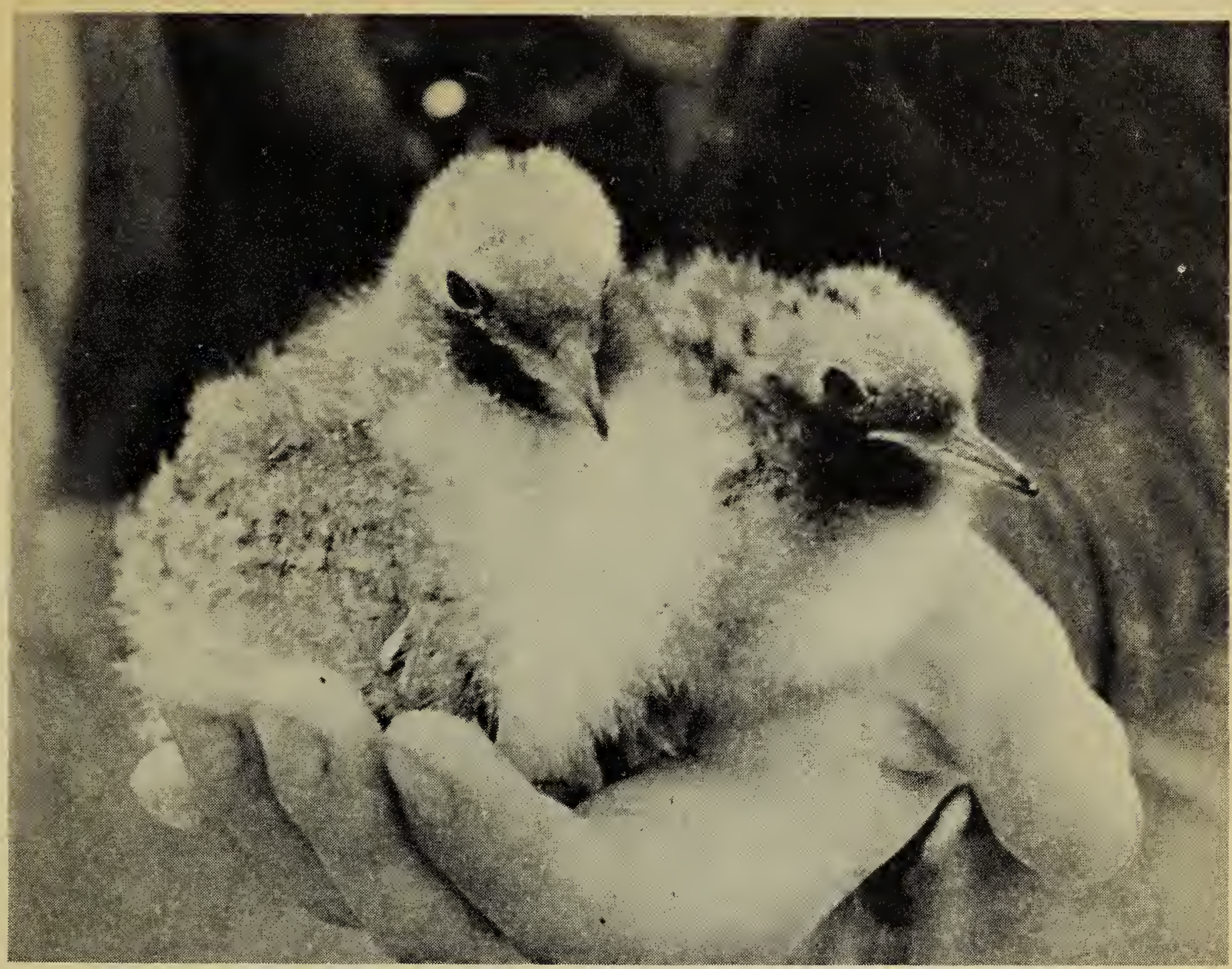

Two Arctic Tern chicks

roundtrip flight from Arctic to Antarctic, formerly attributed to this bird, making it the long-distance migrant champion of the world, is certainly not characteristic of the entire population, though it may well be accomplished by a few individuals." Taverner (1945) remarks appropriately: "It is remarkable that it has not been observed more often in our southern latitudes...."

\section{LITERATURE CITED}

American Ornithologists' Union Committee. 1957. Check-list of North American Birds, Fifth Edition.

Bent, A. C. 1921. Life Histories of North American gulls and terns. U.S. Nat. Mus. Bull. 113. (Reprinted by Dodd, Mead and Co., New York, in 1947).

Bradshaw, F. 1921. Report of the Chief Game Guardian, p.p. 1-53. Annual Report Dept. Agriculture 1921, Gov't of the Province of Saskatchewan, Regina, Sask.

Godfrey, W. E. 1954. Birds of Prince Edward Island, Ann. Rep. Natl. Mus., Bull No. 132., $1952-53$.

Gussow, W. C. 1959. Athabasca formation of western Canada. Bull. Geol. Soc. Amer., 70: $1-18$.

Harper, F. 1915. The Athabaska, Great Slave Lakes Expedition, 1914. Geol. Surv. Dept. Mines. Summ. Rep. 1914. Sessional Faper No. 26, pp. 159-163.
1931. Physiographic and Faunal areas in the Athabaska and Great Slave Lakes region. Ecology, 12: 18-32.

Hawskley, O. 1957. Ecology of a breeding population of Arctic Terns. Bird Banding, $28 ; 57-92$.

Mitchell, H. H. 1924. Birds of Saskatchewan. Canad. Field. Nat., 38: 101-118.

Parmelee, D. F. and S. D. MacDonald. 1960. The birds of west-central Ellesmere Island and adjacent areas. Natl. Mus. Canada, Bull. No. 169 .

Peterson, R. T. 1947. A field guide to the birds. Houghton Mifflin Co., Boston.

Peterson, R. T., G. Mountford and P. A. D. Hollom. 1954. A field guide to the birds of Britain and Europe. Houghton Mifflin Co., Bostan.

Pcugh, R. H. 1953. All the birds of eastern and central North America. Audubon Guides. Doubleday \& Co., Garden City, N.Y.

Preble. E. A. 1908. A biological investigation of the Athabasca-Mackenzie region. Bur. of Biol. Survey, N.A. Fauna No. 27, pp. 574.

Ridgway, R. 1919. The birds of North and Middle America. Bull. U.S. Nat1. Mus. No. 50, Part 8.

Salt, W. R. and A. L. Wilk. 1958. The birds of Alberta. The Queen's Printer, Edmonton.

Snyder, L. L. 1957. Arctic birds of Canada. Univ. of Tononto Press, Toronto.

Taverner, P. A. and G. M. Sutton, 1934. The birds of Churchill, Manitoba. Annals Carnegie Museum, Vol. 23.

Taverner, P. A. 1945. Birds of Canada. Musson Book Co., Ltd., Toronto. 